\title{
Estudios prospectivos poblacionales: las fortalezas de las cohortes históricas
}

\author{
Rodolfo Pizarro, ${ }^{1}$ Walter Masson ${ }^{2}$ \\ ${ }^{1}$ Jefe de Cardiología Hospital Italiano. Master en Efectividad Clinica. \\ ${ }^{2}$ Jefe de Prevención Cardiovascular, Hospital Italiano. \\ Ciudad Autónoma de Buenos Aires, Argentina.
}

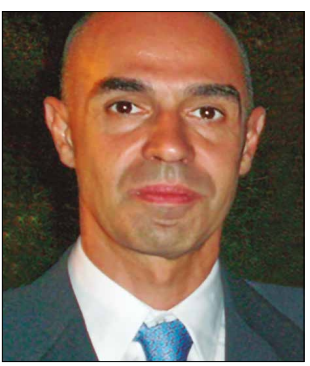

Rodolfo Pizarro
Los estudios de cohortes se caracterizan por ser observacionales, longitudinales y analíticos. En todos ellos se debe considerar una exposición o "factor de exposición", un período de seguimiento predeterminado (que debe ser completo para cada individuo que compone la cohorte, desde el momento de su enrolamiento hasta el fin del período considerado) y el desenlace de un resultado (que dependerá en gran medida del seguimiento de la cohorte). ${ }^{1}$ El período de tiempo predeterminado debe ser suficiente para que todos los sujetos en estudio tengan la opción de desarrollar o no el evento de interés. Asimismo, las eventuales pérdidas del seguimiento no deben superar el $20 \%$, pues esto podría invalidar los resultados.

En pocas palabras, podríamos decir que los estudios de cohorte deben tener una exposición, un periodo de seguimiento y un resultado.

Los estudios de cohorte pueden ser prospectivos (la exposición ocurrió o no, pero el evento todavía no sucedió) o retrospectivos (ya ocurrieron la exposición y el evento). El diseño retrospectivo podría ser especialmente útil cuando el tiempo de latencia es muy largo. La limitación que tiene este tipo de cohorte es que debemos asegurarnos que los datos a recolectar estén registrados (exposiciones y potenciales confundidores). En el caso de los estudios de cohorte prospectivos, es más probable que el registro de los datos "hacia adelante" sea más efectivo.

Entre los objetivos de los estudios de cohorte se destacan: conocer los aspectos de la historia natural o el curso clínico de una enfermedad o de un evento de interés, determinar tasas de incidencia y riesgos, identificar factores protectores o de riesgo para el desarrollo de un evento de interés, estudiar la supervivencia, etc. Las ventajas y desventajas de los estudios de cohorte pueden observarse en la tabla 1.

Tabla 1. Ventajas y desventajas de los estudios de cohorte

Ventajas

Desventajas

Se pueden investigar múltiples resultados que pueden estar asociados con múltiples exposiciones.

Susceptibles a pérdidas durante el seguimiento.

Permiten estudiar el cambio en la exposición y el resultado a lo largo del tiempo.

Útiles para examinar exposiciones raras.

Útiles para medir la incidencia del resultado.

Pueden inferir la causalidad.
No eliminan el riesgo de los factores de confusión no medidos o no registrados.

Susceptibles al sesgo de información y al sesgo del recuerdo (cohorte retrospectiva).

Ineficientes para evaluar eventos raros.

Costosos en tiempo y recursos (mayor en las cohortes prospectivas). 


\section{Estudios de cohortes con base poblacional (estudio Framingham)}

Son estudios de grandes cohortes basadas en una parte de la población definida o en su totalidad, constituyendo un valioso recurso para obtener evidencia científica orientada a la prevención y el tratamiento de las principales enfermedades de la población.

El primer estudio icónico en la patología cardiovascular fue el estudio Framingham de riesgo cardiovascular que se inició en 1948 e incluyó a 5209 hombres y mujeres, entre 30 y 62 años de edad, de la ciudad Framingham (cercana a Boston, de 60000 habitantes), que no padecían síntomas cardiovasculares o cerebrovasculares. ${ }^{2}$ El estudio continuó reclutando a los descendientes de los primeros sujetos incluidos entre los años 1971 y 1975 (conocido como estudio Framingham Offspring).

$\mathrm{El}$ aporte de este gran estudio epidemiológico fue relevante. Gracias al seguimiento de la población durante un largo período de tiempo, se pudo determinar (entre otras cosas) que la edad era un factor de riesgo para la ocurrencia de los eventos vasculares. Además, se comprobó que la patología coronaria (en particular el infarto agudo de miocardio) era dos veces más frecuente en los hombres en comparación a las mujeres y que aparecía más precozmente en el sexo masculino. Asimismo, se estableció la asociación entre ciertos factores de riesgo cardiovasculares (en ese contexto histórico no estaba aún establecido) como la hipertensión arterial, el tabaquismo, la diabetes o el colesterol elevado y el mayor riesgo de presentar un evento cardiovascular. Gracias al seguimiento de la historia natural de la enfermedad aterosclerótica, se formularon nuevos criterios de normalidad y se establecieron conductas activas dirigidas a la prevención cardiovascular.

Finalmente, la construcción de modelos es frecuente en el contexto de los estudios de cohorte. Los investigadores pueden necesitar construir modelos explicativos o predictivos. En el modelo explicativo, el interés se centra en identificar variables que tengan una asociación clínicamente posible y estadísticamente significativa con el resultado o el evento clínico. En cambio, en el predictivo, el objetivo es predecir la probabilidad o el riesgo de presentar en el futuro (pronóstico) el resultado de interés.

A partir de este gran estudio epidemiológico, se desarrollaron funciones o puntajes para predecir el riesgo cardiovascular (modelos predictivos). Estas funciones permiten, en forma práctica y sencilla, la estimación multifactorial del riesgo, considerando el impacto de varios factores de riesgo en forma conjunta.
Los puntajes de riesgo son herramientas muy útiles en la práctica clínica, ya que permiten "clasificar" a las personas en distintos grupos de riesgo y, de esa forma, poder priorizar las intervenciones con fármacos útiles en prevención cardiovascular en aquellos sujetos con un riesgo cardiovascular más elevado.

El primer y clásico puntaje de riesgo cardiovascular surgido de la cohorte de Framingham utiliza un método de puntuación para calcular el riesgo coronario (infarto agudo de miocardio y muerte de origen coronaria) a los 10 años en base a las siguientes variables: edad (35-74 años), sexo, HDL-C, colesterol total, presión arterial sistólica, tabaquismo (sí/no) y medicación para la presión arterial (sí/no). Posteriormente, y basándose en los datos de la cohorte original, otras funciones de riesgo fueron creadas con el objetivo de predecir otros eventos vasculares (o una combinación de ellos). Inclusive, algunos puntajes elaborados estiman el riesgo con un horizonte temporal más prolongado (30 años). ${ }^{3}$ Esto fue posible porque el seguimiento de la cohorte original pudo ser prolongado y la pérdida de información durante el seguimiento (recolección de los datos en el tiempo) no fue relevante.

Sin embargo, los puntajes de riesgo tienen limitaciones relacionadas con la calibración y la capacidad de discriminación. ${ }^{4}$ Esto es así porque las características de la cohorte (tipo de población, momento histórico), de las cuales surge el puntaje de riesgo, no necesariamente son las mismas a las observadas en otras poblaciones donde se quiere aplicar el puntaje.

Idealmente, si queremos utilizar en nuestra población puntajes de riesgo surgidos a partir de otras cohortes, debemos previamente validarlos. La validez es el grado en que un instrumento mide lo que realmente pretende o quiere medir. Para ello, se suele comparar con un estándar de referencia (gold standard). En el caso de las funciones de riesgo, el gold standard será la verdadera proporción de eventos cardiovasculares ocurridos durante un período de tiempo. La validación analiza hasta qué punto lo predicho por el puntaje de riesgo se corresponde con la realidad. En este proceso de validación, se verifica la calibración (compara lo predicho por la función de riesgo con lo observado en la realidad) y la discriminación (capacidad de las funciones de riesgo para distinguir a los pacientes que tendrán o no el evento cardiovascular). En ese sentido, algunos países han adaptado las funciones originales de Framingham luego de validarlas en su población. ${ }^{5}$ Muchas otras cohortes prospectivas en varios países han sido utilizadas para diseñar puntajes de riesgo. Así, por ejemplo, tenemos el 
puntaje PROCAM (Alemania), el QRISK (Reino Unido) o el proyecto SCORE (Europa). ${ }^{6-8}$

En conclusión, los estudios de cohorte constituyen uno de los tipos de estudios observacionales en los que se hace un seguimiento a lo largo del tiempo de un grupo de personas que comparte o no alguna característica (exposición), registrando los resultados (eventos) en uno o más puntos temporales. Como todo tipo de estudio, tiene ventajas y desventajas. La generación de los modelos explicativos y predictivos a partir de este tipo de estudios posee un gran valor científico: el icónico estudio de Framingham es un ejemplo de ello.

\section{Referencias}

1. Wang X, Kattan MW. Cohort Studies: Design, Analysis and Reporting. Chest 2020; 158 (1S): S72-S78.

2. Wilson PW, D'Agostino RB, Levy D, Belanger AM, Silbershatz H, Kannel WB. Prediction of coronary heart disease using risk factor categories. Circulation 1998; 97 (18): 1837-1847.
3. Pencina MJ, D’Agostino RB, Larson MG, Massaro JM, Vasan RS. Predicting the 30-year risk of cardiovascular disease: the Framingham heart study. Circulation 2009; 119 (24): 3078-3084.

4. Baena-Díez JM, Ramos R, Marrugat J. Capacidad predictiva de las funciones de riesgo cardiovascular: limitaciones y oportunidades. Rev Esp Cardiol Supl 2009; 9: 4B-13B.

5. Marrugat J, D’Agostino R, Sullivan L, Elosua R, Wilson P, Ordovas $\mathrm{J}$, et al. An adaptation of the Framingham coronary heart disease risk function to European Mediterranean areas. J Epidemiol Community Health 2003; 57 (8): 634-638.

6. Assmann G, Cullen P, Schulte H. Simple scoring scheme for calculating the risk of acute coronary events based on the 10-year followup of the prospective cardiovascular Münster (PROCAM) study. Circulation 2002; 105 (3): 310-315.

7. Conroy RM, Pyörälä K, Fitzgerald AP, Sans S, Menotti A, De Backer G, et al. Estimation of ten-year risk of fatal cardiovascular disease in Europe: the SCORE project. Eur Heart J 2003; 24 (11): 987-1003.

8. Hippisley-Cox J, Coupland C, Vinogradova Y, Robson J, May M, Brindle P. Derivation and validation of QRISK, a new cardiovascular disease risk score for the United Kingdom: prospective open cohort study. BMJ 2007; 335 (7611): 136. 


\title{
Prospective Population-Based Study: The Strengths of Historical Cohort Studies
}

\author{
Rodolfo Pizarro, ${ }^{1}$ Walter Masson ${ }^{2}$ \\ ${ }^{1}$ Head of Cardiology, Hospital Italiano Master in Clinical Effectiveness. \\ ${ }^{2}$ Head of Cardiovascular Prevention. Hospital Italiano. \\ Ciudad Autónoma de Buenos Aires, Argentina.
}

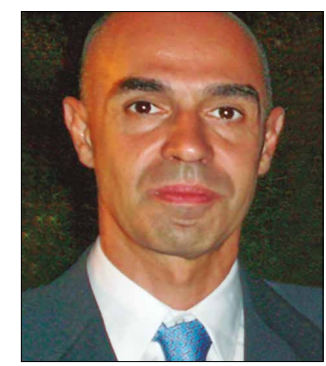

Rodolfo Pizarro
Cohort studies are characterized by being observational, longitudinal and analytical. In all of them, an exposure or "exposure factor" must be considered, a predetermined follow-up period (which must be complete for each individual that makes up the cohort, from the moment of enrollment to the end of the period considered) and the outcome of a result, (which will largely depend on the follow-up of the cohort). ${ }^{1}$ The predetermined period of time should be sufficient for all study subjects to have the option of developing the event of interest or not. Likewise, eventual losses to the follow-up should not exceed $20 \%$, as this could invalidate the results.

In short words, we could say that cohort studies must have an exposure, a follow-up period and an outcome.

Cohort studies can be prospective (the exposure oc- curred or not, but the event has not yet occurred) or retrospective (the exposure and the event have already occurred). The retrospective design could be especially useful when the latency time is very long. The limitation of this type of cohort is that we must ensure that the data to be collected are recorded (exposures and potential confounders). In the case of prospective cohort studies, recording the data "forward" is more likely to be more effective.

The objectives of the cohort studies include: knowing the aspects of the natural history or the clinical course of a disease or an event of interest, determining incidence rates and risks, identifying protective or risk factors for the development of a disease event. interest, study the survival, etc. The advantages and disadvantages of cohort studies can be seen in table 1 .

Table 1. Advantages and Disadvantages of Cohort Studies

Advantages

You can investigate multiple outcomes that may be associated with multiple exposures.

It allows to study the change in the exposure and the result over time.

Useful for examining rare exposures.

Useful to measure the incidence of the result.

You can infer causality.
Disadvantages

Susceptible to losses during the follow up.

It does not eliminate the risk of unmeasured or no recorded confounders.

Susceptible to information bias and recall bias (retrospective cohort).

Inefficient to evaluate rare events.

Costly in time and resources (higher in prospective cohorts). 


\section{Population-Based Cohort Studies (Framingham Study)}

They are studies of large cohorts based on a defined part of the population or in its entirety, constituting a valuable resource to obtain scientific evidence oriented to the prevention and treatment of the main diseases of the population.

The first iconic study in cardiovascular disease was the Framingham study of cardiovascular risk that began in 1948 and included to 5209 men and women between 30 and 62 years of age from the city of Framingham (near Boston, of 60,000 inhabitants) who did not suffer from symptoms cardiovascular or cerebrovascular. ${ }^{2}$ The study continued to recruit the descendants of the first subjects included between the years 1971 and 1975 (known as the Framingham Offspring Study).

The contribution of this large epidemiological study was relevant. Thanks to the monitoring of the population over a long period of time, it was possible to determine, (among other things), that age was a risk factor for the occurrence of the vascular events. In addition, it was found that coronary disease, and (in particular acute myocardial infarction), was twice as frequent in men compared to women and that it appeared earlier in the male sex. Likewise, the association between certain cardiovascular risk factors was established (in that historical context it was not yet established) such as arterial hypertension, smoking, diabetes or high cholesterol and the increased risk of presenting a cardiovascular event.

Thanks to the follow-up of the natural history of atherosclerostic disease new normality criteria were formulated and active behaviors aimed at cardiovascular prevention were established.

Finally, model building is common in the context of cohort studies. Researchers may need to build explanatory models or predictive models. In the explanatory model, the interest is focused on identifying variables that have a clinically possible and statistically significant association with the clinical outcome or event. Instead in the predictive modeling, the goal is to predict the probability or risk of presenting the outcome of interest in the future (prognosis).

From this large epidemiological study, functions or scores were developed to predict cardiovascular risk (predictive models). These functions allow in a practical and simple way the multifactorial estimation of risk, considering the impact of several risk factors together.

Risk scores are very useful tools in clinical practice, since they allow "classifying" people into different risk groups and thus, to prioritize interventions with useful drugs in cardiovascular prevention in those subjects with a risk higher cardiovascular.

The first and classic cardiovascular risk score emerged from the Framingham cohort uses a scoring method to calculate coronary risk (acute myocardial infarction and death of coronary origin) at 10 years based on the following variables: age (35-74 years), sex, HDL-C, total cholesterol, systolic blood pressure, smoking (yes / no) and blood pressure medication (yes / no). Subsequently, and based on the data from the original cohort, other risk functions were created with the objective of predicting other vascular events (or a combination of them). Even some elaborated scores estimate risk with a longer time horizon (30 years). ${ }^{3}$ This was possible because the follow-up of the original cohort could be long. and the loss of information during follow-up (data collection over time) was not relevant. However, risk scores have limitations related to calibration and discrimination ability. ${ }^{4}$ This is so because the characteristics of the cohort (type of population, historical moment) from which the risk score arises are not necessarily the same as those observed in other populations where the score is to be applied. Ideally, if we want to use in our population risk scores arising from other cohorts, we must first validate it. Validity is the degree to which an instrument measures what it really intends or wants to measure. For this, it is usually compared with a reference standard (gold standard). In the case of risk functions, the gold standard will be the true proportion of cardiovascular events that occurred during a period of time. The validation analyzes to what extent the prediction of the risk score corresponds to reality. In this validation process, calibration (compares what is predicted by the risk function with what is actually observed) and discrimination (ability of risk functions to distinguish patients who will or will not have a cardiovascular event). In this sense, some countries have adapted the original Framingham functions, after validating them in their population. ${ }^{5}$

Many other prospective cohorts in various countries have been used to design risk scores. Thus, as an example, we have the PROCAM score (Germany), the QRISK (United Kingdom), or the SCORE project (Europe). ${ }^{6-8}$

In conclusion, cohort studies constitute one of the types of observational studies in which a group of people 
who share or not share some characteristic (exposure) is followed over time, recording the results (events) in one or more time points. Like all types of studies, it has advantages and disadvantages. The generation of the explanatory and predictive models from these types of studies have great scientific value the iconic Framingham study is one such example of it.

\section{References}

1. Wang X, Kattan MW. Cohort Studies: Design, Analysis, and Reporting. Chest 2020; 158 (1S): S72-S78.

2. Wilson PW, D'Agostino RB, Levy D, Belanger AM, Silbershatz H, Kannel WB. Prediction of coronary heart disease using risk factorcategories. Circulation 1998; 97(18): 1837-1847.

3. Pencina MJ, D'Agostino RB Sr, Larson MG, Massaro JM, Vasan RS. Predicting the 30-year risk of cardiovascular disease: the Framingham heart study. Circulation 2009; 119 (24): 3078-3084.
4. Baena-Díez JM, Ramos R, Marrugat J. Predictive capacity of cardiovascular risk functions: limitations and opportunities. Rev Esp Cardiol Supl 2009; 9: 4B-13B.

5. Marrugat J, D'Agostino R, Sullivan L, Elosua R, Wilson P, Ordovas $\mathrm{J}$, et al. An adaptation of the Framingham coronary heart disease risk function to southern European Mediterranean areas. J Epidemiol Community Health 2003; 57(8): 634-638.

6. Assmann G, Cullen P, Schulte H. Simple scoring scheme for calculating the risk of acute coronary events based on the 10-year follow-up of the prospective cardiovascular Münster (PROCAM) study. Circulation 2002; 105(3): 310-315.

7. Conroy RM, Pyörälä K, Fitzgerald AP, Sans S, Menotti A, De BackerG, et al. SCORE project group. Estimation of ten-year risk of fatalcardiovascular disease in Europe: the SCORE project. Eur Heart J 2003; 24(11): 987-1003.

8. Hippisley-Cox J, Coupland C, Vinogradova Y, Robson J, May M, Brindle P. Derivation and validation of QRISK, a new cardiovasculardisease risk score for the United Kingdom: prospective open cohortstudy. BMJ 2007; 335(7611): 136. 